\title{
Spring-mediated skull expansion: overall effects in sutural and parasutural areas. An experimental study in rabbits ${ }^{1}$
}

\author{
Expansão craniana com molas: efeitos globais nas áreas suturais e parassuturais. Estudo \\ experimental em coelhos
}

\author{
Rodrigo de Faria Valle Dornelles ${ }^{\mathrm{I}}$, Vera Lúcia Nocchi Cardim ${ }^{\mathrm{II}}$, Marília Trierveiler Martins ${ }^{\mathrm{III}}$, Ana Carolina Brandão de \\ Campos Fonseca Pinto ${ }^{\mathrm{IV}}$, Nivaldo Alonso ${ }^{\mathrm{V}}$
}

${ }^{\mathrm{I}}$ Fellow Master degree, Plastic Surgery, FMUSP, São Paulo, Brazil.

${ }^{\text {II }} \mathrm{PhD}$, General Surgery, Hospital Beneficência Portuguesa, São Paulo, Brazil.

III Assistant Professor, Buccal Pathology Discipline, Faculdade de Odontologia, USP, São Paulo, Brazil.

${ }^{\text {Iv }}$ Assistant Professor, Surgery Division, Faculdade de Medicina Veterinária, FMVZUSP, São Paulo, Brazil

${ }^{v}$ Assistant Professor, Plastic Surgery Division, FMUSP, São Paulo, Brazil.

\begin{abstract}
Purpose: The use of springs in cranial expansion has proven to be effective in the treatment of craniosynostosis. Spring-mediated expansion has been studied both in the sagittal and in parasagittal regions, especially in scaphocephaly. A rabbit model was used in the present study to analyze the effects of springs on the cranial vault and sutures. Methods: Thirteen 4-week-old New Zealand rabbits were divided into 4 groups: in group I, only amalgam markers were used as control; in group II, amalgam markers were used and sagittal suturectomy was performed; in group III, amalgam markers were used, a sagittal suturectomy was performed and an expansible spring was fitted in the interparietal region and in group IV, markers were used and linear parasagittal craniectomy was carried out with springs. Animals were sacrificed after 2, 4, 8 and 12 weeks. Radiological control and histological analysis were performed in the area of spring implantation. Results: In the groups using springs distraction of the craniectomy borders was greater than in those that did not use springs. New bone formation was observed in all groups, and was faster in group II. Bone growth started from the borders and depth. Bone regeneration presented a similar histological pattern in the groups with spring in the sagittal and parasagittal region. Conclusions: The rabbit model proved to be adequate for the analysis proposed by the study. The use of springs in the groups with sagittal and parasagittal osteotomy led to a similar distraction of amalgam markers and both groups had similar ossification histological pattern.
\end{abstract}

Key words: Osteogenesis, Distraction. Craniofacial Dysostosis. Skull. Rabbits.

\section{RESUMO}

Objetivo: O uso de molas na expansão craniana tem provado ser efetivo no tratamento da craniossinostoses. A expansão com molas tem sido estudada nas regiões sagital e parassagital, especialmente nas escafocefalias. Um modelo com coelho foi usado no presente estudo para analizar os efeitos das molas sobre a calota craniana e suturas. Métodos: Treze coelhos Nova Zelândia, com quarto semanas de vida, foram divididos em quatro grupos: no grupo I, somente marcadores de amálgama foram implantados como controle; no grupo II, marcadores de amálgama foram implantados e foi retirada a sutura sagital; no grupo III, marcadores de amálgama foram implantados, foi retirada a sutura sagital e foi colocada uma mola expansora na região interparietal e no grupo IV, marcadores de amálgamas foram implantados, uma craniectomia linear parassagital foi realizada e foi colocada uma mola expansora. Os animais foram sacrificados com 2, 4, 8 e 12 semanas. Foi realizado controle radiológico e histológico nas áreas de implantação das molas. Resultados: Nos grupos que utilizaram molas a distração das margens ósseas de craniectomia foi maior do que nos grupos que não utilizaram molas. Neoformação óssea foi observada em todos os grupos, tendo sido mais rápida no grupo II. O crescimento ósseo teve início a partir das margens e da profundidade. A regeneração óssea apresentou padrões histológicos similares nos grupos com o uso de molas na região sagital e parassagital. Conclusões: O modelo experimental com coelho provou ser adequado para a análise proposta pelo estudo. O uso das molas nos grupos com osteotomia sagital e parassagital promoveu uma distração similar dos marcadores de amálgamas e ambos os grupos tiveram padrão histológico de ossificação similar.

Descritores: Osteogênese por Distração. Disostose Craniofacial. Crânio. Coelhos.

${ }^{1}$ Research performed at the Experimental Microsurgery Laboratory (LIM4), Faculty of Medicine, University of São Paulo, (FMUSP), Brazil. 


\section{Introduction}

Craniosynostosis is the premature fusion of the cranial suture with consequent cranial deformity. In addition to the brain format, brain function might also be compromised, since limitations of skull development may cause intracranial hypertension, visual disorders, mental retardation and other abnormalities. Surgical treatment with craniectomy was first reported by Lannelongue ${ }^{1}$ and over time several surgeons developed different cranial reshaping techniques using complex osteotomy techniques, interposition of materials between sutures, use of caustic substances to inhibit suture closure and other procedures with high morbidity and mortality rates. In 1986, Persing et $a .^{2}$ published an experimental study with implantable springs for skull expansion. In 1998 and 2003, Lauritzen et al. ${ }^{3}$ described two clinical cases of patients with craniosynostosis using dynamic expansion with implantable internal springs and in 2001, they reported an experimental study showing changes in the growth of rabbit skulls using springs ${ }^{4}$. In 2008, they published the first 100 cases using this device ${ }^{5}$.

Cardim et al. ${ }^{6}$, based on the experience with elastic distraction of the midface and following the pioneer work of the Göteborg group, started using springs in 2002 in cases of craniosynostosis and craniofacial stenosis ${ }^{7}$. Cases of scaphocephaly were operated on with the use of springs by bilateral parasagittal linear craniotomy, with satisfactory cranial expansion and reshaping results, even when the synostotic suture was maintained.

Skull expansion using totally implantable springs is different from the principles of osteogenic distraction, since there is no latency time, the spring starts acting at the time of insertion, and this action is continuous without external control. There is no control of ossification in the area of osteotomy and expansion ceases before the total opening capacity of the spring is exerted. The implant site, number and force of springs have not been established.

The purpose of this experimental study was to use springs on sagittal and parasagittal regions after craniectomy. Radiological and histological slides of the areas with new bone formation were used to assess the results 4,8 and 12 weeks after implant.

\section{Methods}

Thirteen female, New Zealand White (Oryctolagus cuniculus) 4-week-old, rabbits with mean weight of 2,400 $\mathrm{g}$ from the Central Biotery, Medical School, University of São Paulo (FMUSP). The study was carried out at the Experimental Microsurgery Laboratory (LIM4), FMUSP and the animals were kept at the Biotery of this Laboratory throughout the experimental period. Each cage kept a single individual, which were fed and had free access to water, alternating light/dark every 12 hours and at room temperature of $21^{\circ} \mathrm{C}$.

The animals were divided as follows:

* Group I - control group (one animal) cranial vault;
* Group II - control group (four animals)

Parasagittal amalgam markers are implanted and craniectomy is performed along the sagittal suture;

* Group III - (four animals)

Parasagittal amalgam markers are implanted and springs are placed in the suturectomy area;

* Group IV - (four animals)

Parasagittal amalgam markers are implanted and springs are placed at the side of the sagittal suture, without suturectomy.

* The location of amalgam markers and spring are shown in Figure 1.

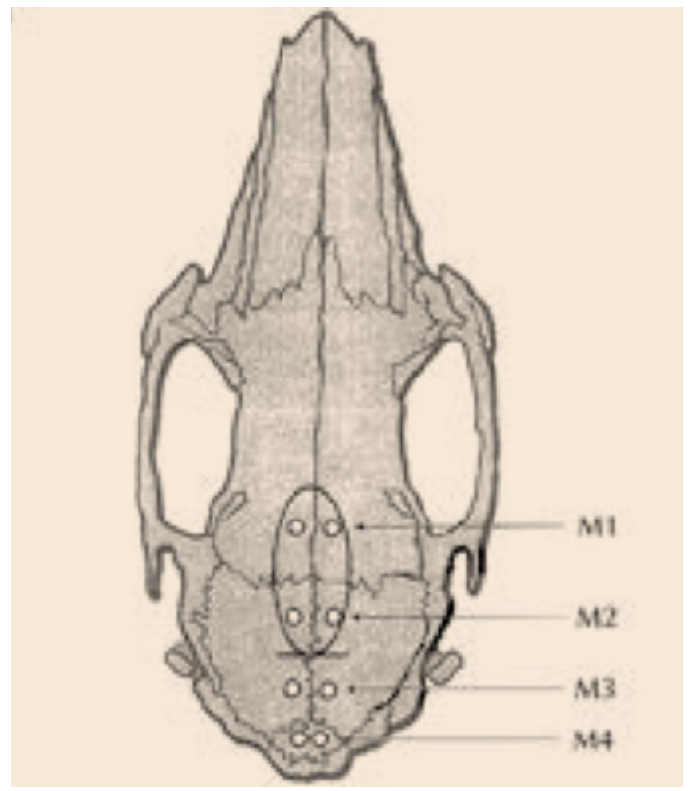

FIGURE 1 - Location of amalgam markers and spring. M1. Marker 1: $5 \mathrm{~mm}$ from the mid line (to the right and left) and $5 \mathrm{~mm}$ anteriorly to the coronal suture; M2. Marker 2: $5 \mathrm{~mm}$ from the mid line (to the right and left) and $5 \mathrm{~mm}$ posteriorly to the coronal suture; M3. Marker 3: $5 \mathrm{~mm}$ from the mid line (to the right and left) and $5 \mathrm{~mm}$ anteriorly to the lambdoid suture; M4. Marker 4: $3 \mathrm{~mm}$ from the mid line (to the right and left) and $5 \mathrm{~mm}$ posteriorly to the lambdoid suture. Presence of spring between M2 and M3

Springs were manually manufactured by the first author using stiff elastic wire (nickel and chrome alloys), used in orthodontics. A 0.020 " bend diameter wire with $18 \mathrm{~mm}$ arm length and $25 \mathrm{~mm}$ of deflection range at rest was used. Measurement for the standardization of the expansion force of all of the springs was performed prior to implantation, with 335 grams of force and an opening of $2 \mathrm{~mm}$ (WAFIOS WG 3/2).

Procedures were performed under antiseptic conditions. Animals were anesthetized with ketamine hydrocloride, at $35 \mathrm{mg} / \mathrm{kg}$ of body weight, combined to xylazin hydrocloride at $5 \mathrm{mg} / \mathrm{kg}$, IM. After anesthesia, a local infusion of lidocaine hydrocloride 
solution diluted at $0.2 \%$, added to adrenalin at a final concentration of 1:200.000, respecting a maximum dose of $7 \mathrm{mg} / \mathrm{kg}$ for lidocaine, was performed. The approach was made by a longitudinal incision of $20 \mathrm{~mm}$ in the cranial region exposing the sagittal suture with minimal periosteal detachment. Amalgam markers were implanted in all animals by craniectomy using a micromotor and a low-rotation $1.8 \mathrm{~mm}$ spherical drill. All animals received a single dose of benzathin benzylpenicillin $100.000 \mathrm{un} / \mathrm{kg}$ IM as a prophylactic antibiotic at the end of the surgery.

In group I incision was closed by approximation and fixation of tissues with continuous stitches using 5-0 monofilament nylon thread.

In group II, a $1.8 \mathrm{~mm}$ wide craniectomy was made including the sagittal suture, extending up to on millimeter beyond the coronal and lambdoid sutures. Sagittal suturectomy was made using a low-rotation $1.8 \mathrm{~mm}$ spherical drill. The incision was closed by approximation and fixation of tissues with continuous stitches using 5-0 monofilament nylon thread.

In group III, a $1.8 \mathrm{~mm}$ wide craniectomy was made including the sagittal suture, extending up to on millimeter beyond the coronal and lambdoid sutures. Osteotomy was performed using a low-rotation $1.8 \mathrm{~mm}$ spherical drill. The spring was placed with minimal dura mater detachment between M2 and M3 (Figure 1). Fixation was maintained by the force of the spring in a bone reentrance made at the craniectomy border. The incision was closed by the approximation and fixation of tissues with continuous stitches using 5-0 monofilament nylon thread (Figure 2).

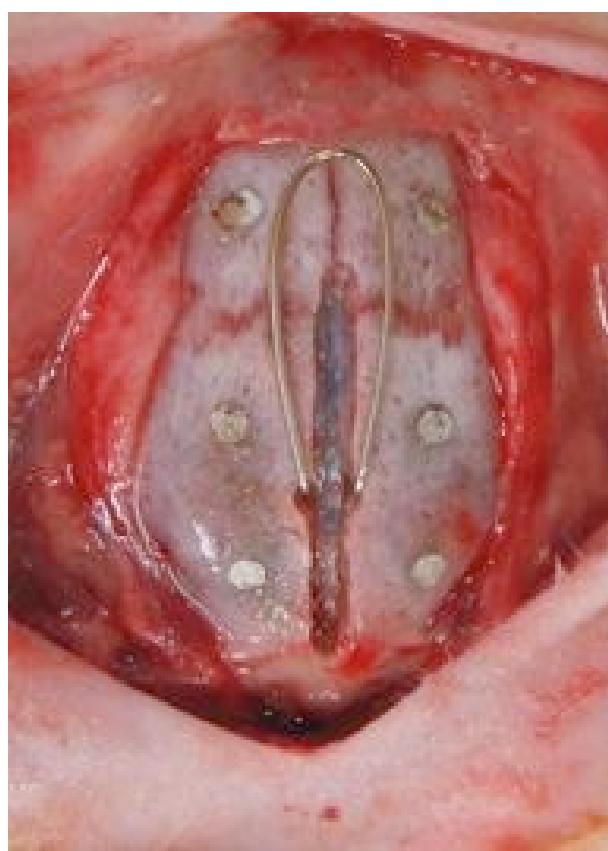

FIGURE 2 - Group III with amalgam markers, suturectomy and implantation of spring between $\mathrm{M} 2$ and M3
In group IV, a $1.8 \mathrm{~mm}$ wide craniectomy line was made at the right parasagittal region and the spring was placed between M2 and M3. The incision was closed by the approximation and fixation of tissues with continuous suture using 5-0 monofilament nylon thread (Figure 3).

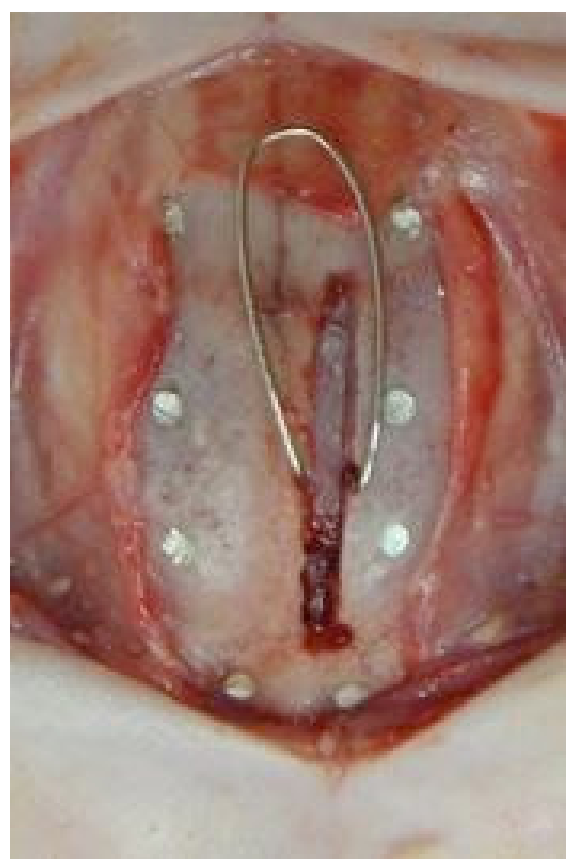

FIGURE 3 - Group IV with placement of amalgam markers, parasagittal linear craniectomy and implantation of spring between M2 and M3

All groups were evaluated 2, 4, 8 and 12 weeks after surgery, using longitudinal weight records (to follow-up weight gain and consequent cranial growth equivalence among individuals), cephalometric data and histological analysis.

Euthanasia was performed using the described anesthesia and subsequent asphyxia with an individual carbon dioxide gas (CO2) chamber.

To obtain histological data for the assessment of new bone formation, samples for the postmortem analysis included slides with a cranial and caudal perspective of the transversal section of the intermediary distance between M2 and M3, coinciding with the spring support (Figure 1). A bone segment was osteotomized using a $1.8 \mathrm{~mm}$ wide drill and was separated from the cranial vault keeping its link with the dura mater (Figure 4). 


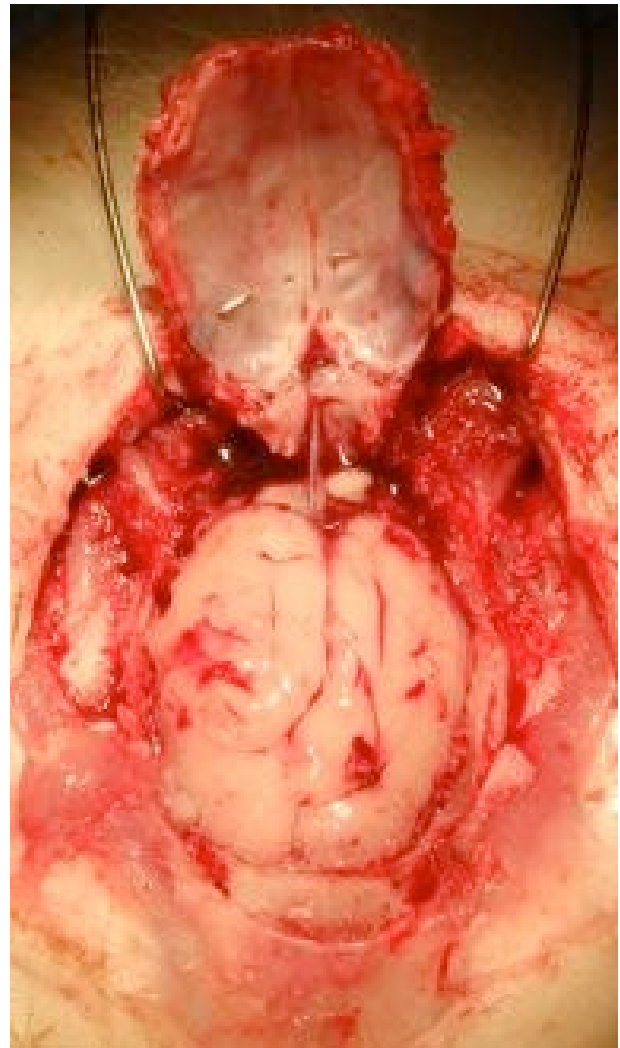

FIGURE 4 - Removal of bone segment. Internal view showing the spring struts and the dura mater continuation

Tissues were fixated in $10 \%$ buffered formol solution and were decalcified with $5 \%$ formic acid. The material was dehydrated in increasing ethanol concentrations, was diaphanized in xylol and embedded in paraffin. A series of tissue sections were sliced perpendicular to the osteotomy line with $5 \mu \mathrm{m}$. Histological analysis was performed with hematoxyllin and eosin (HE) staining.
To obtain craniometrical data and assess the distances between amalgam markers, radiographic tests of the skulls were performed. The animals were anesthetized as previously reported to obtain the adequate position for the radiographic projections. Thus, they were placed in ventral decubitus to obtain ventrodorsal projection. A marker was placed beside the skull, at the same vertical distance as the device, for gauging purposes at the time of measurement of the distances between amalgams and to standardize findings. A $500 \mathrm{~mA}$ and $125 \mathrm{kV}$ RAY-TEC radiodiagnostic device, RT 500/125 model, with a microprocessor controlled system, silicon full-wave rectifier, X-ray table with antidiffusion grid and recipromatic Bucky and rotating anode X-ray tube. Radiographic 24X30 cm TMS-1 and MXG/PLUS films were placed on a metallic chassis with intensifying CRONEX HI plus screens. The films were developed and fixated by an Automated RPXOMAT Processor, after appropriate luminescent identification.

All measurements were carried out by image digitalization and were calculated by the authors using the MIRROR ${ }^{\circledR}$ (Canfield Imaging Systems) program. Metric calibration was started at the millimetered lead marker and the distance among the center of the amalgam markers was measured at M3.

\section{Results}

One animal died due to diarrhea on the seventh postoperative day and was replaced. There was no statistically significant weight gain difference among groups. There was no infection at the surgical site.

\section{Radiological aspect}

Skull expansion measured by implanted amalgam markers showed a greater distraction between the M3 position in the groups with springs than in the group without springs at all time points. The values obtained are shown in Figure 5.

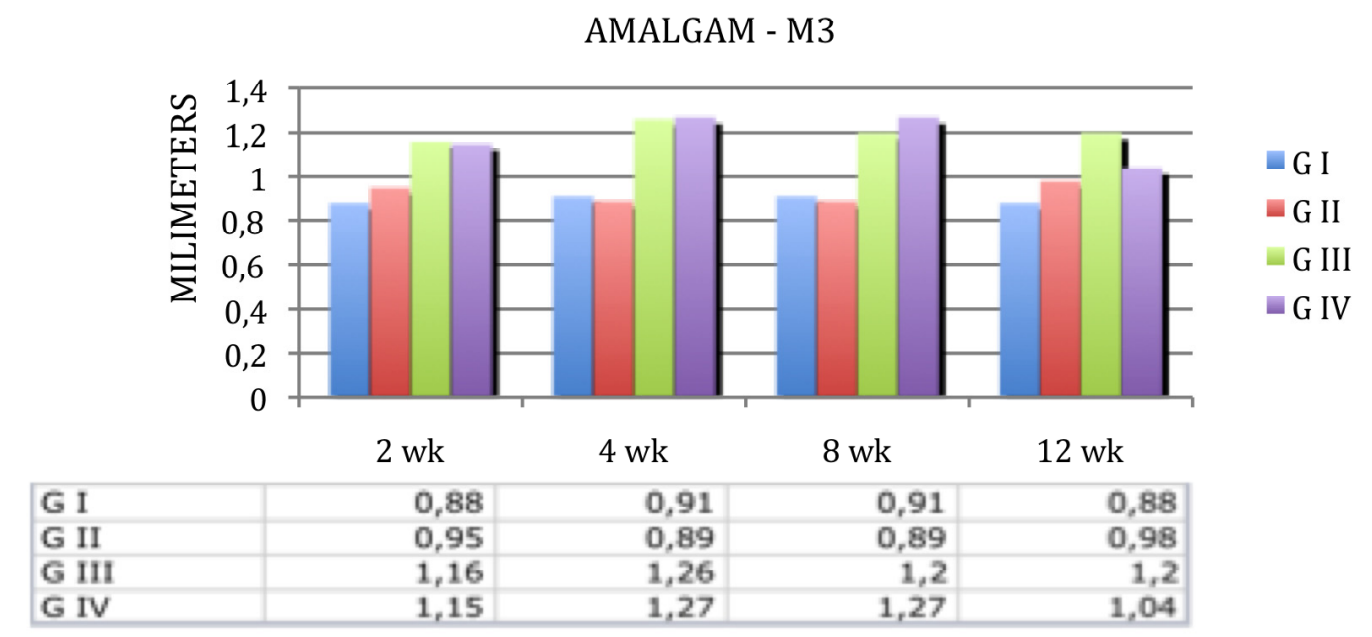

FIGURE 5 - Distraction measurements among amalgams in M3 


\section{Histological aspect}

* 2 weeks (Figure 6)

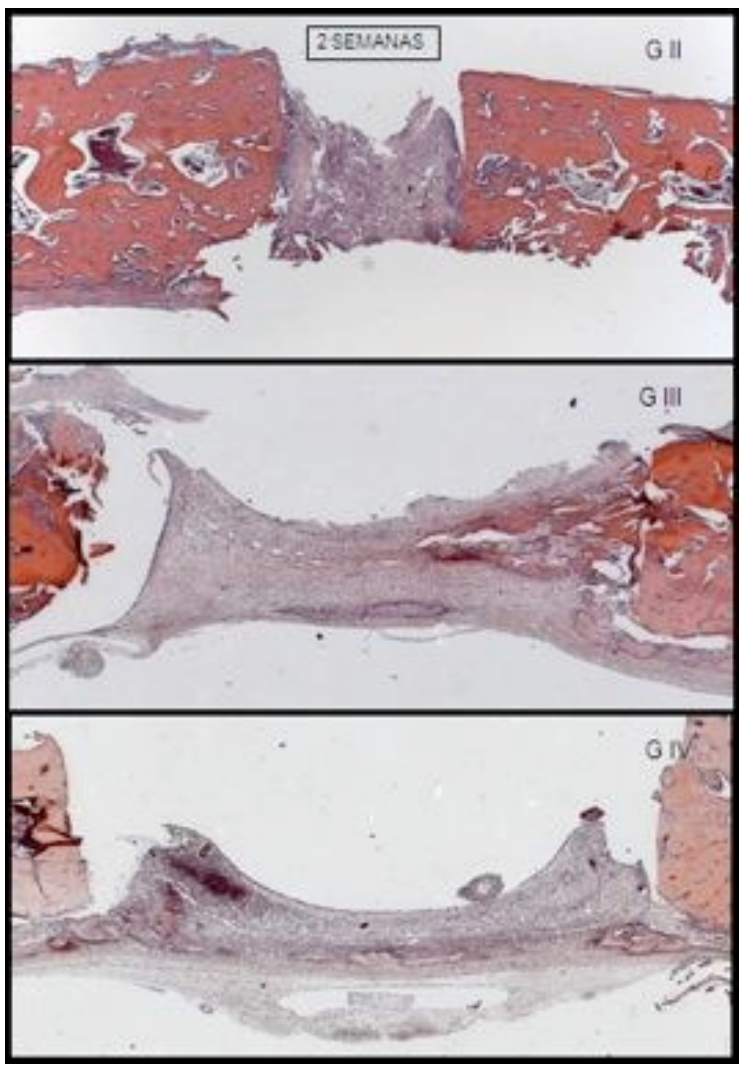

FIGURE 6 - Histological slides of the skull at M3 in Groups II, III and IV after 2 weeks

Group II: Histological slides showed dense and cellularized conjunctive tissue, with young fibroblasts and newly formed vessels, in addition to a moderate mononuclear inflammatory infiltrate, characterizing granulation tissue, which fills the region of bone defect. There is intense peripheral activity at the margins of the defect as well as initial bone deposition. Rare and small mineralized tissue fragments are observed around the granulation tissue.

Group III: the defect region was totally filled out by young and cellularized tissue and permeated by mononuclear inflammatory infiltrate. Initial bone deposition may be observed both in the bone stump and in the conjunctive tissue permeation region.

Group IV: Histological slides showed granulation tissue permeated by mild diffuse mononuclear inflammatory infiltrate with several newly formed vessels displaying important areas of new bone fomation, which are concentrated around one of the stumps and also in the internal region.

$$
* 4 \text { weeks }
$$

Group II: the region of bone defect is almost totally filled by new bone tissue still under intense deposition activity. The internal bone surface has less new bone formation than the external surface.

Group III: The area of bone defect has intense new bone formation in the format of young trabeculae and globose depositions scattered throughout the remaining granulation tissue.

Group IV: The region of bone defect is filled almost exclusively by young conjunctive tissue. There is deposition of immature bone tissue in the format of trabeculae, bound to the lateral stumps.

\section{* 8 weeks (Figure 7)}

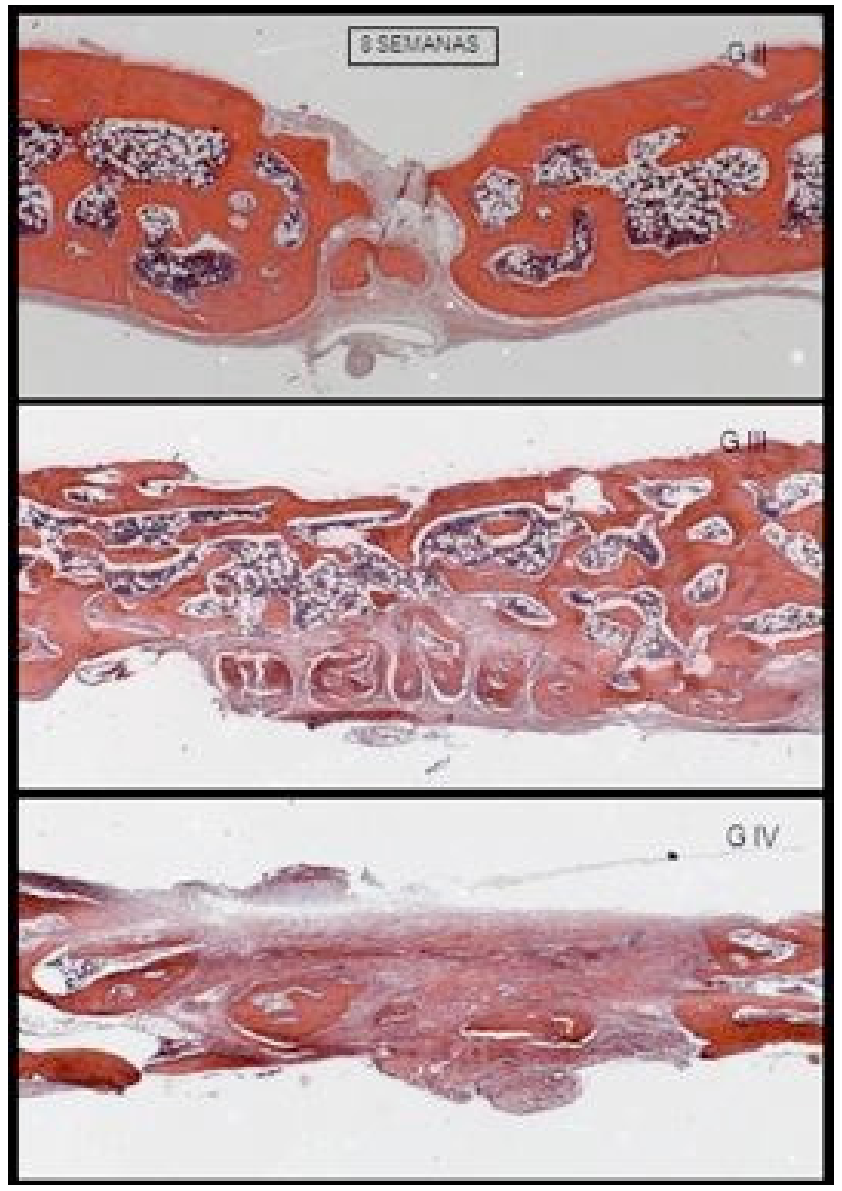

FIGURE 7 - Histological slides of the skull at M3 in Groups II, III and IV after 8 weeks

Group II: For this group, the status is identical to Week 2.

Group III: the external region of the cortical bone is beginning to form lamellae and gaps are filled by osteocytes, with regular disposition. Along this cortical, immature trabeculae fill out the width of the defect. In the internal region, bone deposition is in a less advanced stage and young conjunctive tissue may still be observed, however without inflammatory infiltrate.

Group IV: Although significant new bone formation is observed, there is no continuous cortical bone on the external surface. Moreover, the areas filled by young conjunctive tissue are more abundant than in group III. 
*12 weeks

Group I: The histological analysis of the cranial vault showed normal aspect of the cortical and trabecular bone.

Group II: The slides show initial bone tissue organization with sutural aspect. Bone tissue is almost totally lamellar. Hematopoietic bone marrow with normal aspect fills the gaps between the trabeculae.

Group III: results in this group are inconclusive.

Group IV: the region of bone defect is totally filled by trabeculae of lamellar bone tissue and hematopoietic bone marrow with normal aspect. The thickness of the deposited bone is smaller than in the remaining areas.

\section{Discussion}

The experimental model was adequate. The brain growth curve is similar to the brain growth curve in humans, with perinatal brain development and easily exposed cranial sutures, which contributed for the observations.

Springs made of orthodontic wire with standardized opening tension were used in this study and had enough expansion force to increase the distraction between markers. The rabbits did not have synostosis and spring-mediated cranial expansion was demonstrated. Ten Cate $^{10}$ also demonstrated cranial expansion in rabbits and defined regeneration as the remodeling of an injured organ or tissue with consequent complete restoration of the original architecture. He suggested that sutural expansion involves an injury followed by a repair phenomenon, which, in other tissues, leads to the formation of scar tissue, however, regeneration takes place in the suture area. He also compared the suture's behavior to that of gomphosis (bone, ligament, tooth), which as fibrotic joints have a similar response to expansion techniques. Thus, the groups using springs acquired bone reshaping of the osteotomized areas when homeostasis between the pressure of the springs and intracranial pressure was achieved, which stabilized the expansor mechanism and led to ossification.

Person et al. ${ }^{11}$ reported that suture removal is not followed by significant changes in the angular dimensions of the cranial base in non-synostotic animals, and therefore the behavior of cranial expansion mediated by springs may be validated, since craniometric variation proved to be independent of suture removal. On the other hand, Mooney et al..$^{12}$ and Putz et al. ${ }^{13}$ demonstrated changes in the cranial base and in intracranial pressure when suturectomies were performed in synostotic rabbits. This observation is essential for the understanding of skull behavior when subjected to expansion, since in addition to the expansor force exerted by the springs, the effect is strengthened by increased intracranial pressure, which enables ossification to take place once it is stabilized.

In 1986, Persing et l. $^{2}$ published a study in rabbits with immobilization of the unilateral coronal suture at 9 days of age, inducing craniosynostosis. At 60 days of age suturectomy was performed and expansible springs were implanted. Greater expansion was observed in the group with springs. However, histological analysis was not reported.

Morphometric measurement methods are not comparable ${ }^{13}$, and therefore comparison among different studies are not possible. However, conclusions of a specific project may be valid. The evolution of cranial expansion is indirectly affected by minimal traumas, such as the implantation of amalgams in cranial expansion ${ }^{14}$; variations in the animal's weight; changes in the growth vector of the adjacent sutures and cranial base ${ }^{13}$; spring-induced erosion ${ }^{16}$ and others. The expansion degree observed in the groups with spring was similar, however, it was greater in both groups than in the group without springs, confirming the role of springs in cranial expansion and indicating a similarity between the group with sagittal spring and the group with parasagittal spring, even though suture was maintained in the latter.

As reported by Gewalli et al. ${ }^{5}$, despite the quick opening of the spring when compared to the established bone distraction procedures ${ }^{17}$, ossification takes place in the gap between the stumps distracted by springs. We agree with the hypothesis that a smaller detachment of the dura mater may be associated to this finding ${ }^{18}$, which is clearly evidenced by Gosain ${ }^{19}$ who also observed that the defect created in adult animals was maximized by the maintenance of contact with the pericranium (bone growth from peripheral areas) and dural contact (bone growth from the central area). A similar finding was observed in Group III and IV slides (Figure 4).

As reported by Mabbutt $^{20}$, in the present study the pericranium was not approximated and bone deposition took place both from the stumps and in isolated islets in the lower part along the dura mater. On the second week all groups presented inflammatory tissue and immature bone standards. During the first 4 postoperative weeks there was increased deposition activity with further stabilization, as well as a synchronism in the maturation of newly formed tissue, where group II presented bone growth earlier when compared to group III and when group III was compared to group IV. After 12 weeks uniform bone regeneration was observed in the expanded area in Groups III and IV, however, the overall thickness of the vault was lower than in Group II.

\section{Conclusions}

Spring-mediated cranial expansion in rabbits has similar evolution standards when the device is implanted directly in the removed suture area as well as when it is implanted in the parasagittal region. Interparietal distraction is similar and the histological behavior of regeneration follows the same pattern. The use of springs in nonsutural areas must be better understood taking into consideration the vectors of cranial growth.

\section{References}

1. Lannelongue M. De la craniectomie dans la microcephalie. Cr Acad Sci. 1890;110:1382-5. In: Guimarães-Ferreira J, Miguéns J, Lauritzen C. Advances in craniosynostosis research and management. Adv Tech Scand Neurosurg. 2004;29:23-83.

2. Persing JA, Babler WJ, Nagorsky MJ, Edgerton MT, Jane JA. Skull expansion in experimental craniosynostosis. Plast Reconstr Surg. 1986;78(5):594-603. 
3. Lauritzen C, Sugawara Y, Kocabalkan O, Olsson R. Spring mediated dynamic craniofacial reshaping. Case Report. Scand J Plast Reconstr Surg Hand Surg. 1998;32(3):331-8.

4. Gewalli F, Da Silva Guimarães-Ferreira JP, Maltese G, Ortengren U, Lauritzen C. Expander elements in craniofacial surgery: an experimental study in rabbit. Scand J Plast Reconstr Surg Hand Surg. 2001;35(2):149-56. 5. Lauritzen C, Davis C, Ivarsson A, Sanger C, Hewitt TD. The evolving role of springs in craniofacial surgery: The first 100 clinical cases. Plast Reconstr Surg. 2008;121(2):545-54.

6. Cardim VLN, Dornelles RFV, Salomons RL, Vela SV. Distracción elástica del tercio medio en la disyunción craneo-facial. Cir Plast Iberolatinoam. 2002;28(4):267-75.

7. Cardim VLN, Dornelles R, Salomons RL, Lima e Silva A, Silva AS. Tratamento das craniossinostoses com expansão dinâmica por meio de molas implantáveis: análise de 17 casos. Rev Soc Bras Cir Craniomaxilofac. 2007;10(2):41-50.

8. Wong L, Dufresne CR, Richtsmeier JT, Manson PN. The effect of rigid fixation on growth of the neurocranium. Plast Reconstr Surg. 1991;88(3):395-403.

9. Cardoso ES, Cançado RP, Heltz C, Gerhardt de Oliveira M. Estudo exploratório descritivo do emprego de coelhos brancos da nova zelândia (orytolagus cuniculus) como modelo animal na avaliação dos padrões de crescimento craniofacial. Rev Odonto Ciênc. 2007;22(55):66-71.

10. Ten Cate AR, Freeman E, Dickinson JB. Sutural development: structure and its response to rapid expansion. Am J Orthod. 1977;71(6):622-36.

11. Persson KM, Roy WA, Persing JA, Rodeheaver GT, Winn HR. Craniofacial growth following experimental craniosynostosis and craniectomy in rabbits. J Neurosurg. 1979;50(2):187-97.

12. Mooney MP, Siegel MI, Burrows AM, Smith TD, Losken HW, Dechant
J, Cooper G, Kapucu MR. A rabbit model of human familial, nonsyndromic unicoronal suture synostosis. I. Synostotic onset, pathology, and sutural growth patterns. Childs Nerv Syst. 1998;14:236-46.

13. Putz DA, Smith TD, Burrows AM, Cooper GM, Dechant J, Losken HW, Siegel MI, Mooney MP. Cranial base changes following coronal suturectomy in craniosynostotic rabbits. Orthod Craniofac Res. 2001;5(2):90-103.

14. Alberius P, Malmberg M, Persson S, Selvik G. Variability of measurements of cranial growth in the rabbit. Am J Anat. 1990;188(4):393-400.

15. Davis C, Windh P, Lauritzen CGK. Spring-assisted cranioplasty alters the growth vectors of adjacent cranial sutures. Plast Reconstr Surg. 2008;123(2):470-4.

16. Losken HW, Mooney MP, Zoldos J, Tschakaloff A, Burrows AM, Smith TD, Cooper GM, Kapucu MR, Siegel MI. Internal calvarial bone distraction in rabbits with delayed-onset coronal suture synostosis. Plast Reconstr Surg. 1997;102(4):1109-19.

17. Ilizarov GA. The tension-stress effect on the genesis and growth of tissues. Part II. The influence of the rate and frequency of distraction. Clin Orthop. 1989;239:263-85.

18. McCarthy JG, Schreiber J, Karp N, Thorne CH, Grayson BH. Lengthening the human mandible by gradual distraction. Plast Reconstr Surg. 1992;89(1):1-8.

19. Gosain AK, Santoro TD, Song L, Capel CC, Sudhakar PV, Matloub HS. Osteogenesis in calvarial defects: contribution of the dura, the pericranium, and the surrounding bone in adult versus infant animals. Plast Reconstr Surg. 2002;112(2):515-27.

20. Mabbutt LW, Kokich VG. Calvarial and sutural re-development following craniectomy in the neonatal rabbit. J Anat. 1979;129(2):413-22.

\section{Correspondence:}

Rodrigo de Faria Valle Dornelles

Núcleo de Plástica Avançada

Rua Martiniano de Carvalho, 907

01321-001 São Paulo - Brazil

Phone/Fax: (55 11)3284-2355

rodrigo@npa.med.br

Conflict of interest: none

Financial source: none

Received: September 10, 2009

Review: November 11, 2009

Accepted: December 16, 2009

\section{How to cite this article}

Dornelles RFV, Cardim VLN, Martins MT, Alonso N. Spring-mediated skull expansion: overall effects in sutural and parasutural areas. An experimental study in rabbits. Acta Cir Bras. [serial on the Internet] 2010 Mar-Apr;25(2). Available from URL: $\underline{\text { http://www.scielo.br/acb }}$ 